\title{
Calcium hydroxide nanoparticles for deacidification of canvas oil paintings
}

\author{
${ }^{1}$ Mohammad L. Hassan, ${ }^{2}$ Osama M. Elfeky, ${ }^{3}$ Nehad S. Ahmed \\ 1_Cellulose and Paper Department \& Centre of Excellence for Advanced Sciences, \\ National Research Centre, 33 El-Behouth street, Dokki, Giza, Egypt. \\ ml.hassan@nrc.sci.eg \& mlhassan2012@gmail.com
}

2_ Restoration and Conservation Department, Faculty of Archaeology Cairo University, 12622 Giza, Egypt.

3_ Researcher, Faculty of Archaeology Cairo University\& Fine Art Sector,1 Kafor Street, Dokki, Giza, Egypt.

\begin{abstract}
Oil paintings consist of several layers, cellulose is the main components of all types supports of oil painting either it was canvas, paper or wood. The deacidification of canvas oil painting was studied. Cellulose is oxidized by air and hydrolyzed by water vapor, The oxidation process creates acid groups that lower the $\mathrm{pH}$ of the canvas which cause the loss of canvas oil paintings mechanical properties. Nanoparticles of $\mathrm{Ca}(\mathrm{OH}) 2$ can be dispersed in different solvents (e.g. short chain alcohols) and applied on canvas, to balance acidity and long-term protection. The characterization of nanoparticles was carried out by transmission electron microscopy (TEM), regular shape of particles can be seen. Scanning electron microscope (SEM) show stable fiber of cellulose. Canvas samples were artificially aged after deacidification using calcium hydroxide nanoparticles dispersed in short chain alcohols. Cellulose pyrolysis temperature and samples' $\mathrm{pH}$ were evaluated after and before the artificially aging, the applied deacidification treatments raised samples $\mathrm{pH}$ to slightly basic values, these values remained constant upon artificial aging.
\end{abstract}

Keywords:canvas, cellulose, Calcium hydroxide, Nanoparticles, acidification, deacidification

\section{1_Introduction}

Canvas as a support for oil paintings was used in ancient Egyptian civilization and introduced in Italy by the end of the 15th century( Bruyn et al 1986). 
Linen used in ancient oil painting supports, the main component of it was the Cellulose (Cataldi et al 2015). Cellulose, a natural polymer consists of several hundred to over ten thousand D-glucose units linked each other by a $\beta$-(1,4)-glycosidic bond, which can be presented as linear chains. The degree of polymerization (DP) of native cellulose varies between 7,000 and 15,000 (Baglioni et al 2016). Agreat number of hydrogen bonds formed between hydroxyl groups either of the same chain (intramolecular bonds) or of different chains (intermolecular bonds), which cause The structure of cellulose (Medronho et al 2012). The main cause of cellulose degradation is both of hydrolysis and oxidation that affected by $\mathrm{pH}$ degree, temperature, moisture content and degree of crystallinity and happened for $\beta$-(1,4)-glycosidic bonds of cellulose linear chains, which results in the depolymerization of cellulose then the loss of mechanical properties of canvas oil paintings (Calvini 2005; Banait \& Jencks1991; Lundgaard et al 2004). Glucuronic, glucaric, uronic and aldaric acids that promote hydrolysis can found as a result for cellulose oxidation in the so-called spiraling effect (Shanani and Harrison 2002). In the case of canvas, EU-PROPAINT project have shown that levels of trapped organic acids within a frame of easel paintings exceed recommended levels of 1,000 $\mu \mathrm{g} / \mathrm{m} 3$ and could cause long-term damage (Grøntoft 2010). Several methods have been proposed and applied in the past decades to counter cellulose degradation and work out a methodology for conservation and restoration of the effects of acidity (Baty et al 2010). Aqueous solutions of bicarbonate $(\mathrm{PH}=8.5)$ or hydroxides such as $\mathrm{Ca}(\mathrm{OH}) 2(\mathrm{PH}=$ 10.5) were used to treat acidity in paper either by immersion or spraying (Barrow \& Sproull 1959), but aqueous reatments lead to swelling of cellulose fibers (Hackney \& Ernst 1994). Wei T'O (magnesium methoxy methylcarbonate in a volatile solvent) non aqueous method used for deacidification treatment (Burgess et al 1992). Academic and technical backgrounds was provided by nanoscience and nanotechnology to formulate innovative systems for conservation and restoration science (Baglioni \& Giorgi 2006; Baglioni et al 2009 ; Blee \& Matisons 2008 ). Numerous methods and applications of nanoscience have been introduced in the conservation of cultural heritage, especially the calcium hydroxide nanoparticles for wall painting consolidation and paper,canvas and wood deacidification (Ambrosi et al 2001; Daniele et al 2008; Rodriguez-Navarro\& Ruiz-Agudo 2018; Hansen et al 2003 ; Giorgi et al 2002 ; Giorgi et al 2005; Giorgi \& Chelazzi \& Baglioni 2005 ; Poggi et all 2011 ). Carbonates and hydroxides such as calcium and magnesium, are selected for the deacidification of cellulose-based artworks (Baglioni et al 2013; Chelazzi et al 2013), 
due to their high reactivity in nanoparticles size they provide a stable neutral environment by rapidly turning into carbonates (Poggi et al 2013). Crystalline calcium carbonate is produced only a few days after treatment with the calcium hydroxide nanoparticles, due to the reaction of hydroxide with carbon dioxide from the air.( Giorgi et al 2010)

In this paper, the effects of the deacidification for canvas with calcium hydroxide nanoparticles dispersed in alcohols obtained and investigated. Low polar solvents (such as short chain alcohols usually used for dispersing nanoparticles). Nanoparticles were characterized by transmission electron microscopy (TEM), scanning electron microscope (SEM).The deacidification efficacy was assessed by $\mathrm{pH}$, TGA upon an aging at high temperature and relative humidity $(\mathrm{RH})$.

\section{2_ Materials and Methods:}

\subsection{Materials}

For nanoparticles syntheses, n-propanol (99\%), calcium chloride and sodium hydroxide were used. Linen used as canvas samples, Sulfuric acid (96\%) was used for the acidification of canvas samples. pure water (having a resistivity of $18 \mathrm{M} \Omega \mathrm{cm}$ ) was Used while measuring pH. (Daniele et al 2008).

\subsection{Synthesis of $\mathrm{Ca}(\mathrm{OH}) 2$ Nanoparticles and characterization}

The method started from two aqueous solution of calcium chloride $(0.3 \mathrm{M})$ and sodium hydroxide $(0.6 \mathrm{M})$, a surfactant agent (Triton X-100) was added and then the solutions were mixed together maintained at the temperature of about $90^{\circ} \mathrm{C}$, the alkaline solution of $\mathrm{NaOH}$ was added "drop by drop" to the CaCl2.( Taglieri 2013; Daniele et al 2008) several deionised water washings were performed to remove the $\mathrm{NaCl}$ produced and the surfactant too, we carried out a partially substitution of the initial dispersing medium (water) with 2-propanol (Taglieri 2014 ; Rodriguez-Navarro\& Ruiz-Agudo 2018).

Transmission electron microscopy (TEM) was carried out using high-resolution transmission electron microscopy, HR-TEM (JEM-2100 transmission electron microscope, JEOL, Tokyo, Japan), the dried particles morphology of the samples under study,canvas samples were investigated using a FEI Quanta 200 scanning electron microscope SEM (FEI Company, Eindhoven, The Netherlands) at an acceleration voltage of $20 \mathrm{Kv}$, after treatment using $\mathrm{Ca}(\mathrm{OH}) 2$ Nanoparticles. 


\subsection{Preparation of canvas sample}

Linen canvas samples were prepared about 5 pieces each one (about $3 \times 3 \mathrm{~cm}$ ) and (Weight $0.256 \mathrm{~g}$ ) kept at $25^{\circ} \mathrm{C}$ and $50 \% \mathrm{RH}$ for 2 days.

\subsection{1. pH measurement}

canvas (Blank sample) placed in $20 \mathrm{~mL}$ of ultrapure water (having a resistivity $8 \mathrm{M} \Omega$ $\mathrm{cm} \& \mathrm{pH}=7.4$ ) in Closed vial, the vial were kept under stirring for $1 \mathrm{~h}$, before measuring the $\mathrm{pH}$ of the extraction using a digital $\mathrm{pH}$ meter (Hanna Microprocessor-based Bench $\mathrm{pH} / \mathrm{mV} /{ }^{\circ} \mathrm{C}$ Meters, $\mathrm{PH} 210$ ) (Poggi et al 2013).

\subsubsection{Canvas acidification}

Canvas samples were immersed in $\mathrm{H}_{2} \mathrm{SO}_{4}$ aqueous solution $(\mathrm{pH}=2)$ for $40 \mathrm{~min}$. The canvas samples were left to dry for 1 day in ambient conditions. Samples' $\mathrm{pH}$ were recorded before and after the acidification treatment.

\subsubsection{Canvas deacidification}

After acidification canvas sample was treated with $10 \mathrm{ml}$ of nanoparticle dispersions $8 \mathrm{~g} /$ L. The treatments were applied using a micropipette, directly dropping on to the samples to wet them as possible, The treated samples were then left to drying and carbonation procedure in the air at $50 \% \mathrm{RH}$ (controlled) for 10 days.Then $\mathrm{PH}$ were recorded and compared with canvas sample which have acidification treatment.

\subsubsection{Thermal Behavior}

The thermal behavior of all canvas samples was studied using an (SDT Q600 TA Instrument) sample were placed inside an aluminum pan and analyzed. From the thermal curves, the temperature defined as the maximum of the weight loss derivative, was recorded (Soares 1995 ; Franceschi 2001 ; Sandu et al 2003 ).

\subsubsection{Evaluation the treatment of $\mathrm{ca}(\mathrm{HO}) 2$ nano particles by hydrothermal aging}

Blank Samples were treated with $(6 \mathrm{ml})$ of nanoparticle dispersions $8 \mathrm{~g} / \mathrm{L}$. Strong hydrothermal conditions for aging the sample artificially, the samples were placed in a sealed vessel. 
which was put in an oven set at $80{ }^{\circ} \mathrm{C}$. Inside the sealed vessel, the humidity was kept at $75 \%$ using a sodium chloride saturated aqueous solution. Before the aging samples were kept for 1 week at $25{ }^{\circ} \mathrm{C}$ and $50 \% \mathrm{RH}$. (Poggi et al 2013). Sample pH and Tmax were monitored before and after the aging.

\subsubsection{FTIR analysis}

The FTIR spectrometer is used to study textile fibers and the extent of cellulose fiber degradation and also to evaluate treatments (Garside \& Wyeth 2003). The measurement was performed on the ORIGIN JASCO infrared spectroscopy in the wave range 400: $4000 \mathrm{~cm}^{-}{ }^{1}$. Measurements were made for the blank sample, the sample treated with sulfuric acid, and the sample treated with nano-calcium hydroxide for the deacidification.

\section{Results and discussion}

TEM image of calcium hydroxide nanoparticles is shown in Figure.1, where the regular shape of particles can be seen, the diameter of the nanoparticles ranged from 5-8 nm.

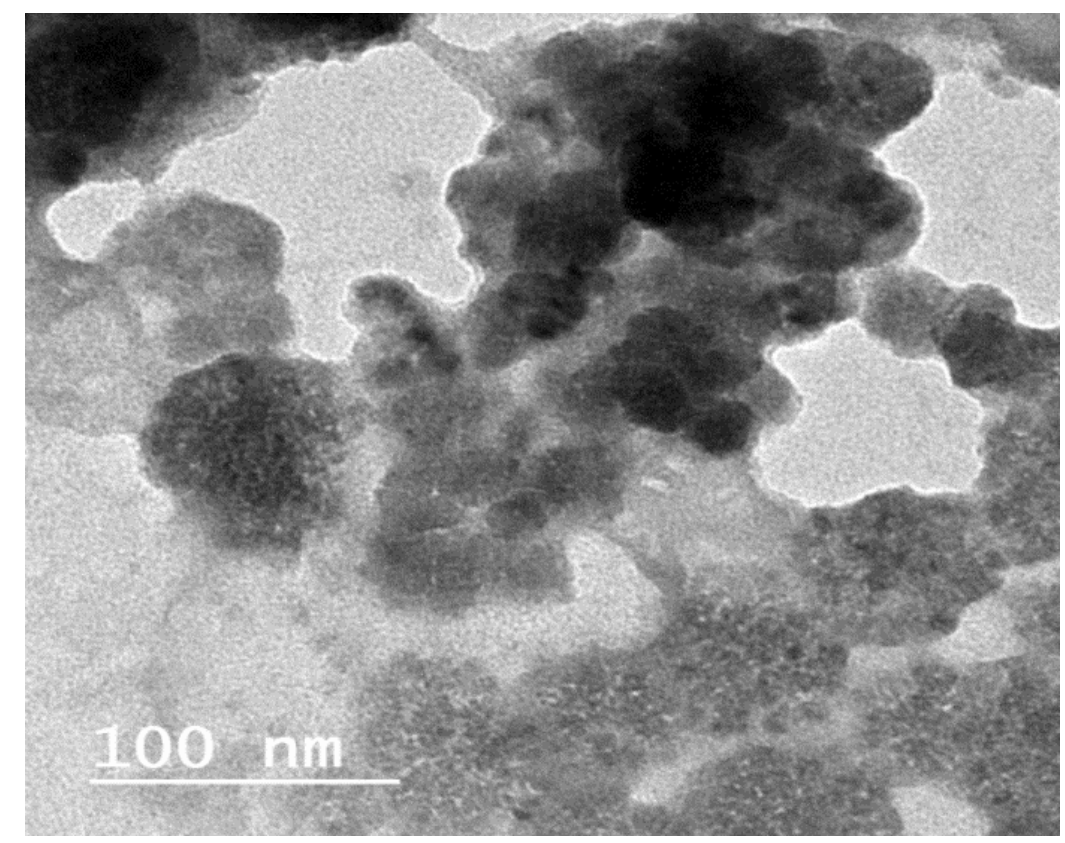

Fig.1 TEM image of $\mathrm{Ca}(\mathrm{OH}) 2$ nanoparticles dispersed in n-propanol 
SEM image in Figure 2 reported some calcium hydroxide particles bound to the cellulose fibers after deacidification by $\mathrm{Ca}(\mathrm{OH})_{2}$ nanoparticles dispersed in $n$ propanol.

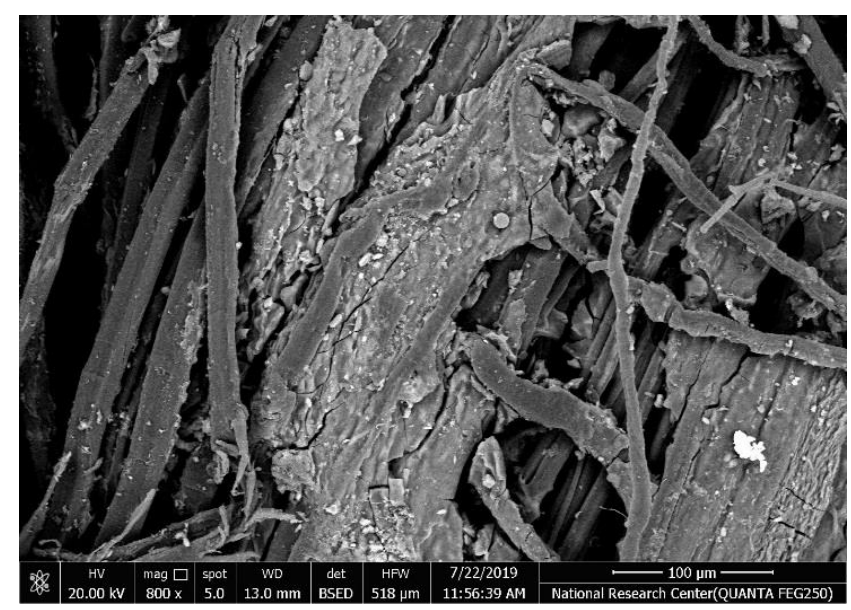

Fig.2 SEM image of deacidified canvas, particles bound to the cellulose fibers which appear stable bar $=100 \mu \mathrm{m}$

SEM images in Figures 3 show calcium hydroxide particles bound to the cellulose fibers after aging.

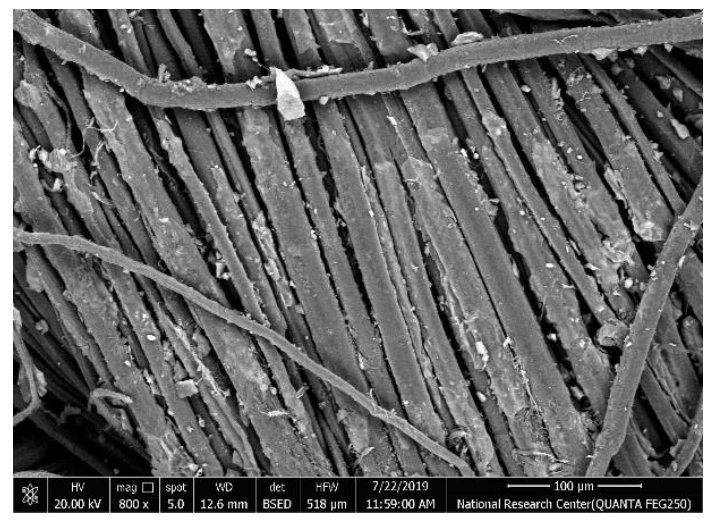

(a)

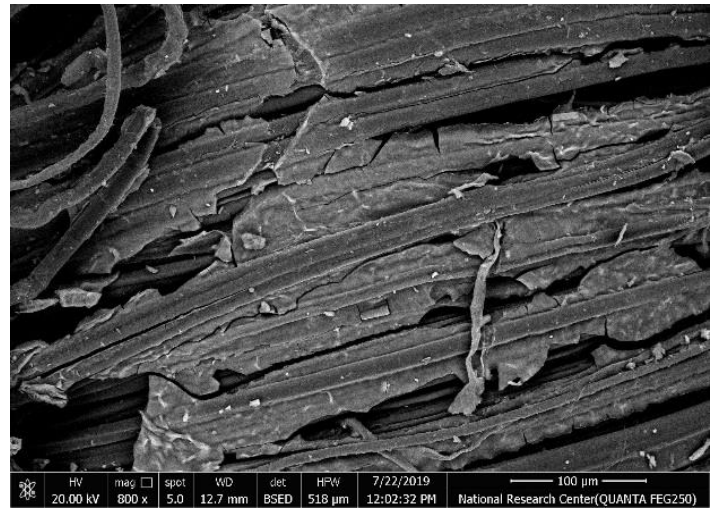

(b)

Fig. 3 SEM images of deacidified canvas after aging for $150 \mathrm{hrs}$ (a) and $300 \mathrm{hrs}$ (b). bar $=100 \mu \mathrm{m}$. 
The recorded $\mathrm{pH}$ of artificially acidified canvas samples was $(\mathrm{pH}=3.7)$. The applied deacidification treatments raised samples $\mathrm{pH}$ to slightly basic values $(\mathrm{pH}=8)$. After 10 days at $50 \% \mathrm{RH}$, samples show $\mathrm{pH}=7$

Table 1. $\mathrm{pH}$ of canavas samples blank, after acidification and after deacidification.

\begin{tabular}{|c|c|}
\hline Sample name & pH \\
\hline Blank sample before acidification & 7.4 \\
\hline Sample after acidification & 3.7 \\
\hline Sample after deacidification & 7 \\
\hline
\end{tabular}

The recorded $\mathrm{pH}$ of artificially aging for $150 \mathrm{hrs}$ canvas sample was $(\mathrm{PH}=7)$ and still recording $(\mathrm{PH}=7)$ after aging for $300 \mathrm{hrs}$, almost reestablished the $\mathrm{PH}$ of the original canvas cellulose

Table 2. $\mathrm{pH}$ of canavas samples after $\mathrm{ca}(\mathrm{HO}) 2$ nano particles treatment and after aging.

\begin{tabular}{|c|c|}
\hline Sample name & $\mathrm{pH}$ \\
\hline Sample after treatment & 8 \\
\hline Sample after aging $150 \mathrm{hrs}$ & 7 \\
\hline Sample after aging $300 \mathrm{hrs}$ & 7 \\
\hline
\end{tabular}

Table 3. Maximum weight loss temperature $\left(T_{\max }\right)$ from TGA curves of canavas samples before and after acidification, deacidification and after aging. 


\begin{tabular}{|c|c|}
\hline Sample name & $\mathbf{T}_{\max }\left({ }^{\circ} \mathbf{C}\right)$ \\
\hline Blank sample before acidification & 373 \\
\hline Sample after acidification & 360 \\
\hline Sample after deacidification & 363 \\
\hline Sample after aging for $150 \mathrm{hrs}$ & 374 \\
\hline Sample after aging for $300 \mathrm{hrs}$ & 370 \\
\hline
\end{tabular}

First derivative of TGA curves in Figures 5 show that the acidifying treatment decreased the $\mathrm{T}_{\mathrm{m}}$ value of cellulose in the canvas samples from 373 to $360^{\circ} \mathrm{C}$. The benefits arising from the deacidification treatments to be $363{ }^{\circ} \mathrm{C}$, in terms of resistance to thermal degradation.

After aging for $150 \mathrm{hrs} \mathrm{T}_{\mathrm{m}}$ value was $373^{\circ} \mathrm{C}$ and after aging for $300 \mathrm{hrs} \mathrm{T}_{\mathrm{m}}$ value was 370 ${ }^{\circ} \mathrm{C}$ almost reestablished the thermal behavior of the original canvas cellulose.

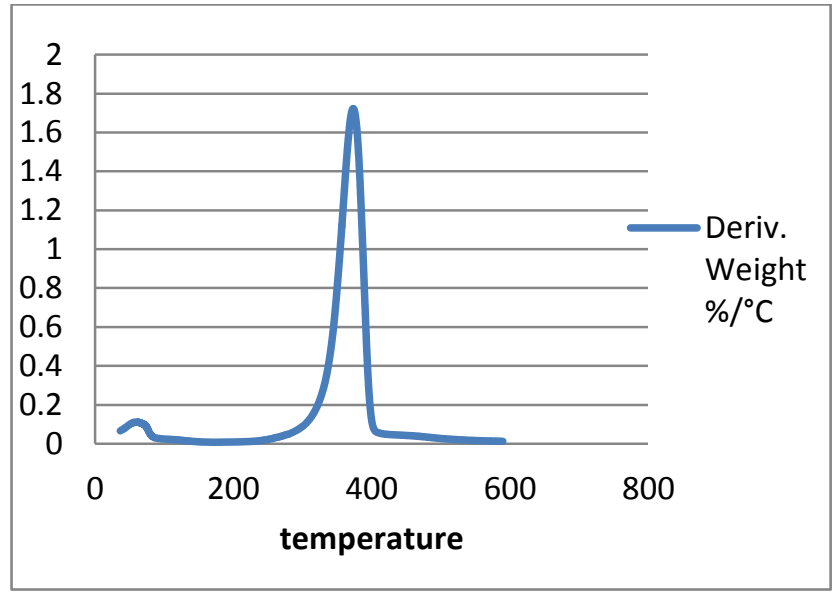

(a) 


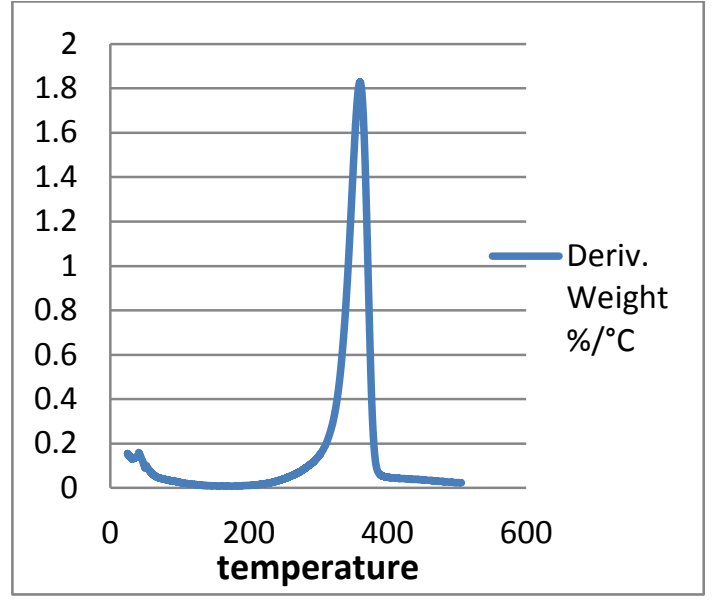

(b)

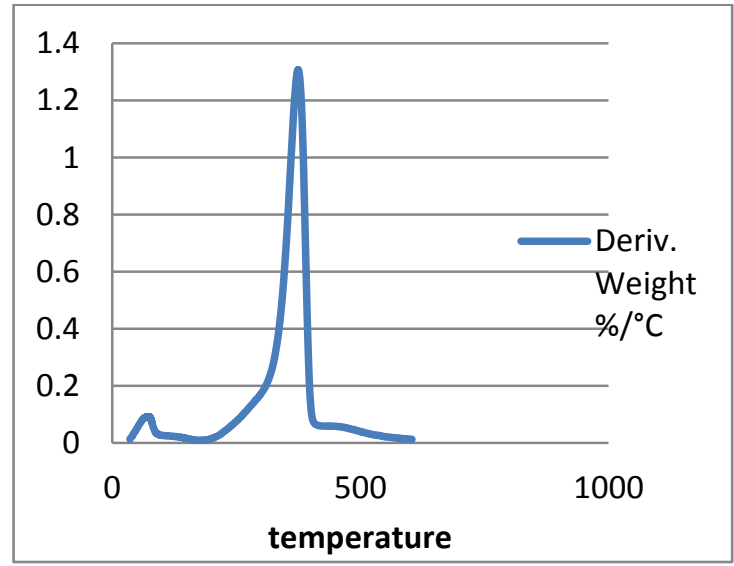

(d)

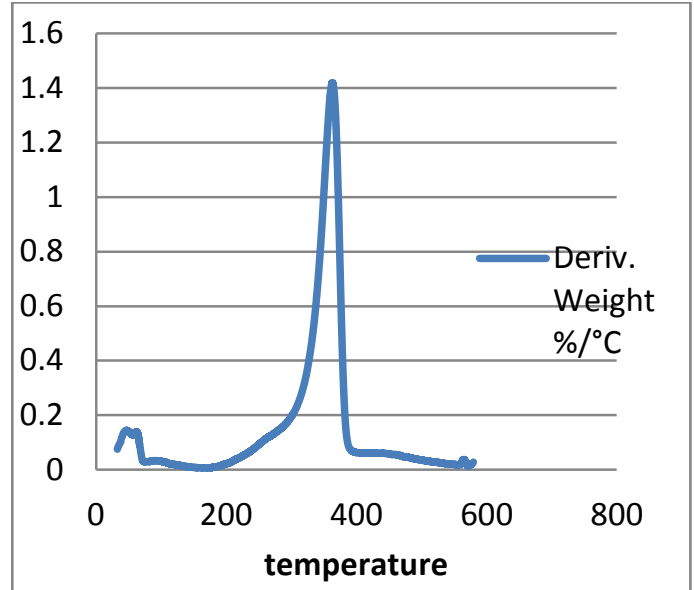

(c)

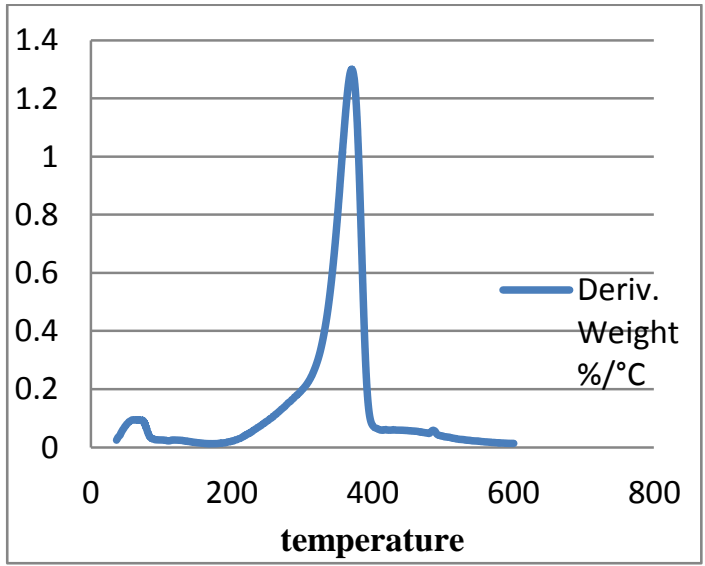

(e)

Figure 5. First derivative of thermogravimetric analysis curves of canvas samples. (a) blank canvas, (b) canvas sample after acidification, (c) canvas sample after deacidification, (d) canvas sample after aging for $150 \mathrm{hrs,} \mathrm{(e)} \mathrm{canvas} \mathrm{sample}$ after aging for $300 \mathrm{hrs}$.

Characteristic infrared bands of Blank Linen sample (Łojewski et al 2010) is shown in Table 4. Figure 6 .The strong band centered at $3442 \mathrm{~cm}^{-1}$ of linen, indicates the presence of hydroxyl groups and is assigned to the stretching $v(\mathrm{OH})$ vibrations. 
These bands are indicative of inter and intermolecular hydrogen bonds. The band at $2900 \mathrm{~cm}^{-1}$ is assigned to stretching vibrations of methyl and ethyl groups $v(\mathrm{CH} 3)$ and $v(\mathrm{CH} 2)$ (cellulose compounds). The broad band at $1640 \mathrm{~cm}-1$ is assigned to vibrations of $v(\mathrm{C}=\mathrm{C})$ (lignin compounds), $\delta(\mathrm{OH})$, and $v(\mathrm{CO})$ bonds (derived from carbonyl,or aldehydic, or carboxyl groups). The bands at 1426 and $1381 \mathrm{~cm}^{-1}$ are assigned to bending vibrations of methyl and ethyl groups $v(\mathrm{CH} 3)$ and $v(\mathrm{CH} 2)$ (cellulose compounds). The band at $1054 \mathrm{~cm}^{-1}$ is assigned to $\mathrm{C}-$ Obridge stretching and $\mathrm{C}-\mathrm{O}-\mathrm{C}$ pyranose ring skeletal vibration ( $\beta$-glycoside linkages, cellulose compounds). The band at $612 \mathrm{~cm}^{-1}$ is assigned to C-OH out-of-plane bending.

Table 4. The functional groups in Linen sample

\begin{tabular}{|c|c|c|}
\hline Wave-number $(\mathrm{cm}-1)$ & Functional group bands & Assignment \\
\hline 3442 & OH stretching & Cellulose \\
\hline 2921 & $\begin{array}{l}\mathrm{C}-\mathrm{H} 2 \text { and } \mathrm{CH} 3 \\
\text { stretching }\end{array}$ & (cellulose compounds) \\
\hline 1640 & $\begin{array}{l}\text { vibrations of } \mathrm{v}(\mathrm{C}=\mathrm{C}) \\
\text { Absorbed } \mathrm{O}-\mathrm{H} \text { and } \\
\text { conjugated } \mathrm{C}=\mathrm{O}\end{array}$ & $\begin{array}{l}\text { lignin compounds } \\
\text { derived from carbonyl, } \\
\text { or aldehydic, or carboxyl } \\
\text { groups }\end{array}$ \\
\hline 1426 and 1381 & $v(\mathrm{CH} 3)$ and $v(\mathrm{CH} 2)$ & (cellulose compounds) \\
\hline 1054 & $\begin{array}{c}\mathrm{C}-\mathrm{O} \text { bridge stretching } \\
\mathrm{C}-\mathrm{O}-\mathrm{C}\end{array}$ & $\begin{array}{l}\text { ( } \beta \text {-glycoside linkages, } \\
\text { cellulose compounds }\end{array}$ \\
\hline 612 & $\begin{array}{l}\mathrm{COH} \text { out-of-plane } \\
\text { bending }\end{array}$ & Cellulose \\
\hline
\end{tabular}


Figures 7\&8 Show characteristic infrared bands of the sample treated with sulfuric acid, and the sample treated with nano-calcium hydroxide for the deacidification.

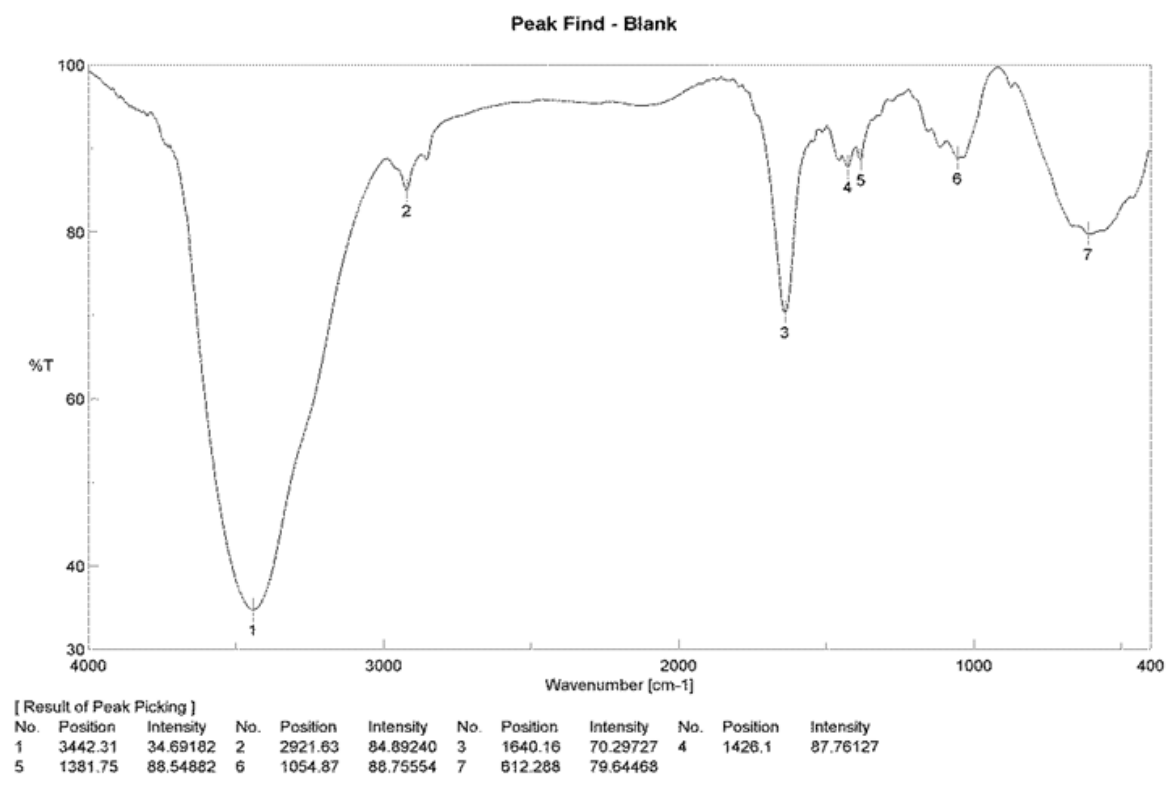

Figure 6. Infrared bands of Blank sample in the wave range 400: $4000 \mathrm{~cm}^{-1}$ 


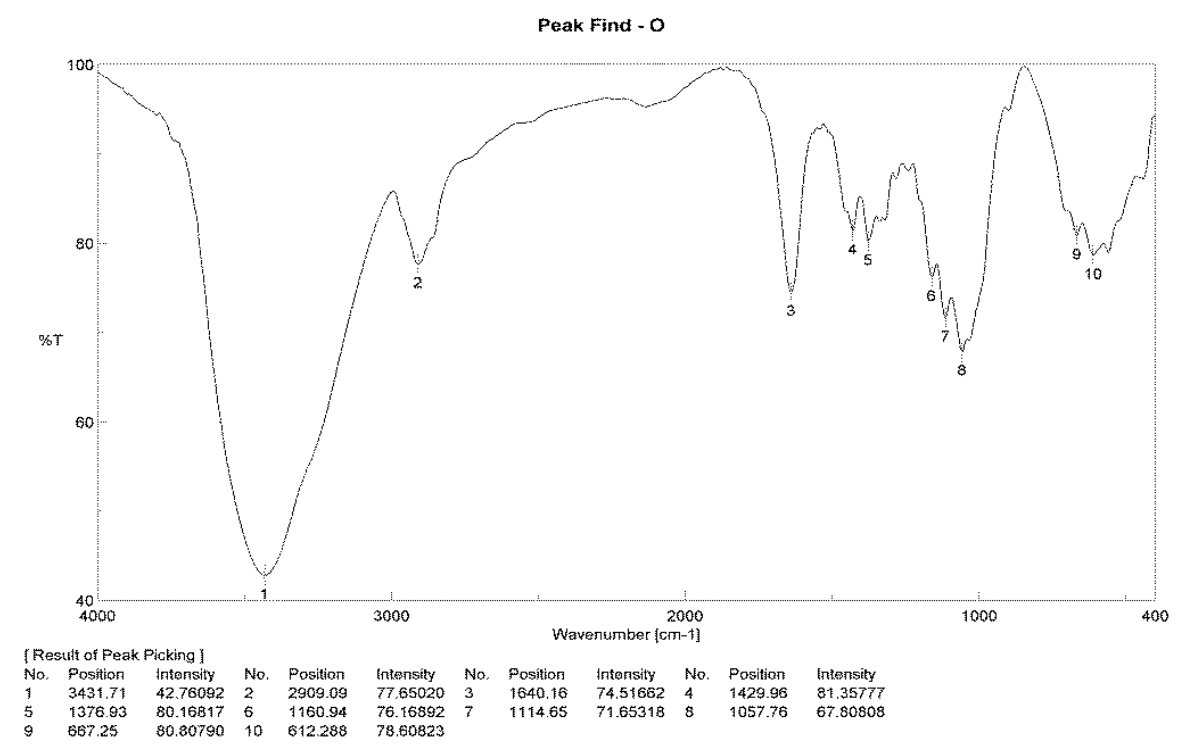

Figure 7. Infrared bands of the sample treated with sulfuric acid in the wave range 400: $4000 \mathrm{~cm}-1$

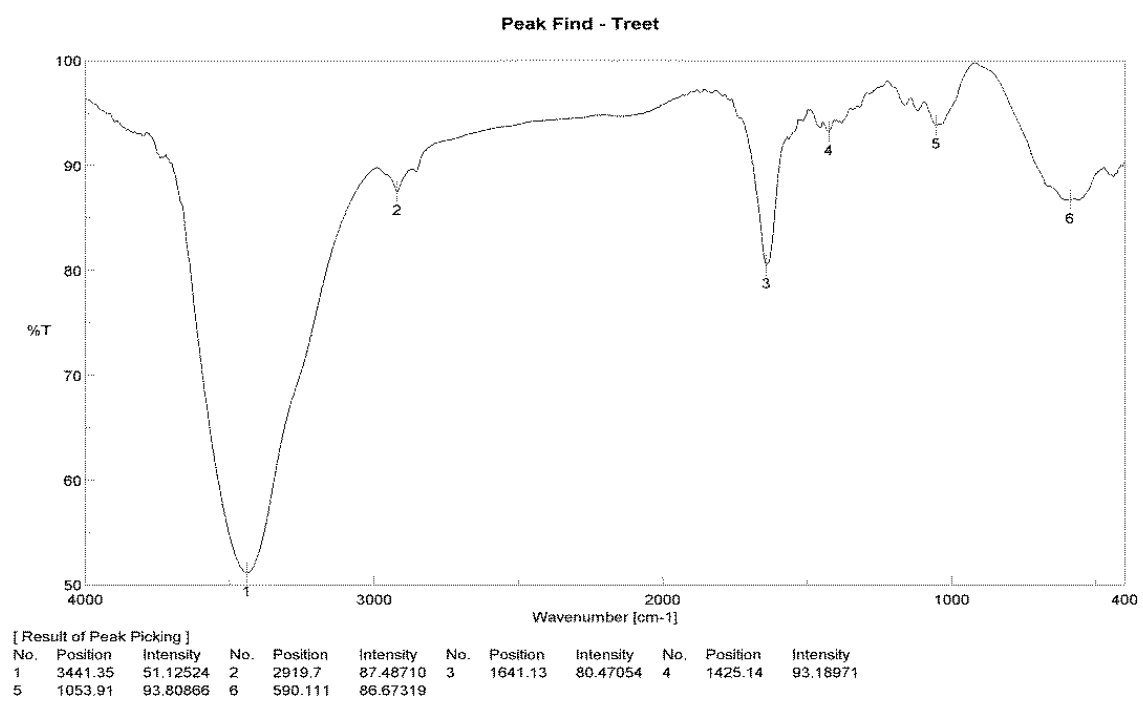

Figure 8. Infrared bands of the sample treated with nano-calcium hydroxide for the deacidification in the wave range 400: $4000 \mathrm{~cm}-1$ 
Spectrum of the sample treated with sulfuric acid have a change occurred, various carbonyl groups have formed in the next oxidation step or aldehydes ending as carboxyls at stretching between 1160_1057 $\mathrm{cm}^{-1}$. Spectrum of the sample treated with nano-calcium hydroxide for the deacidification is similar to the characteristic of blank sample, That means the perfect effect of using calcium nano hydroxide without side effects in the deacidification of canvas.

\section{Conclusions}

Calcium hydroxide nanoparticles, were used for the deacidification of cellulose-based material such as canvas oil painting. Calcium hydroxide nanoparticles showed high stability and dispersibility even at high concentrations in n-propanol, and did not require any further treatment before the application. A higher surface area grants higher reactivity to acids and carbon dioxide. The latter transforms the excess of hydroxides in carbonates, which are milder deacidifying agents that remain as a buffer against reoccurring acidity.The prepared nanostructures were highly crystalline with average diameter of about $8 \mathrm{~nm}$. The deacidification efficacy of dispersion was evaluated on acidified canvas model samples, artificially aged at high temperature and $\mathrm{RH}$. After the deacidification, the $\mathrm{pH}$ of samples was almost neutral and remained constant upon the aging, creating a safe environment in which cellulose depolymerization is inhibited. TGA measurements showed resistance of treated cellulose to thermal degradation. Infrared bands of the Linen treated with nanocalcium hydroxide for the deacidification show that it can return acidification Linen to the original similar to natural linen.

In conclusion, these new formulations expand the palette of available tools for the conservation of canvas oil paintings, these treatments aim to impart an alkaline reserve which will act to buffer the cellulose against the further development of acidity.

\section{References}

1_Ambrosi, M., Dei, L., Giorgi, R., Neto, C., \& Baglioni, P. (2001). Colloidal Particles of $\mathrm{Ca}(\mathrm{OH}) 2$ : Properties and Applications to Restoration of Frescoes. Langmuir, 17(14), 4251-4255. doi: 10.1021/1a010269b 
2_Baglioni, P., \& Giorgi, R. (2006). Soft and hard nanomaterials for restoration and conservation of cultural heritage. Soft Matter, 2(4), 293. doi: 10.1039/b516442g

3_ Baglioni, P., Giorgi, R., \& Dei, L. (2009). Soft condensed matter for the conservation of cultural heritage. Comptes Rendus Chimie, 12(1-2), 61-69. doi: 10.1016/j.crci.2008.05.017

4_Baglioni, P., Chelazzi, D., Giorgi, R., \& Poggi, G. (2013). Colloid and Materials Science for the Conservation of Cultural Heritage: Cleaning, Consolidation, and Deacidification. Langmuir, 29(17), 5110-5122. doi: 10.1021/la304456n.

5_Baglioni , P. , Chelazzi, D., Giorgi, R., Xing, H. \& Poggi, G. (2016) Alkaline Nanoparticles for the Deacidification and pH Control of Books and Manuscripts .In P. Dillmann, L. Bellot-Gurlet \& I. Nenner, Nanoscience and Cultural Heritage. Paris.

6_Banait, N. S., \& Jencks, W. P. (1991). General-acid and general-base catalysis of the cleavage of .alpha.-D-glucopyranosyl fluoride. Journal of the American Chemical Society, 113(21), 7958-7963. doi:10.1021/ja00021a022.

7_Barrow, W., \& Sproull, R. (1959). Permanence in Book Papers: Investigation of deterioration in modern papers suggests a practical basis for remedy. Science, 129(3356), 1075-1084. doi: 10.1126/science.129.3356.1075

8_Baty JW, Maitland CL, Minter W, Hubbe MA, Jordan-Mowery SK (2010) Deacidification for the conservation and preservation of paper-based works: a review. BioResources 5:1955-2023

9_Blee . A \& Matisons .J.G. (2008). Nanoparticles and the conservation of cultural heritage, Material Science Forum, 32, pp. 121-128.

10_Bruyn, J., Haak, B., Levie, S.H., van Thiel, P.J.J.( 1986). Rembrandt Research Project, A Corpus of Rembrandt Paintings,vol.2, 1631_1634. The Art Bulletin, p.15.

11_Burgess HD, Kaminska EM, Boronyak-Szaplonczay A (1992) Evaluation of commercial mass deacidification processes: Akzo-DEZ, Wei T'o and fmc-mg3. Phase I: naturally aged papers. Canadian Conservation Institute, Ottawa 
12_Cataldi, A., Berglund, L., Deflorian, F. and Pegoretti, A. (2015). A comparison between micro- and nanocellulose-filled composite adhesives for oil paintings restoration. Nanocomposites, 1(4), pp.195-203.

13_Calvini, P. (2005). The Influence of Levelling-off Degree of Polymerisation on the Kinetics of Cellulose Degradation. Cellulose, 12(4), 445-447. doi: 10.1007/s10570-005-2206-z.

14_Chelazzi, D., Poggi, G., Jaidar, Y., Toccafondi, N., Giorgi, R., \& Baglioni, P. (2013). Hydroxide nanoparticles for cultural heritage: Consolidation and protection of wall paintings and carbonate materials. Journal Of Colloid And Interface Science, 392, 42-49. doi: 10.1016/j.jcis.2012.09.069.

15_Daniele, V., Taglieri, G., \& Quaresima, R. (2008). The nanolimes in Cultural Heritage conservation: Characterisation and analysis of the carbonatation process. Journal Of Cultural Heritage,9(3), 294-301. doi: 10.1016/j.culher.2007.10.007

16_Franceschi, E., Palazzi, D., \& Pedemonte, E. (2001). Journal search results - Cite This For Me. Journal Of Thermal Analysis And Calorimetry, 66(1), 349-358. doi: 10.1023/a:1012428824378

17_Garside, P., \& Wyeth, P. (2003). Identification of Cellulosic Fibres by FTIR Spectroscopy - Thread and Single Fibre Analysis by Attenuated Total Reflectance. Studies In Conservation, 48(4), 269-275. doi: 10.1179/sic.2003.48.4.269

18_Giorgi,R., Dei,L., Ceccato,M., Schettino,C.\& Baglioni,P.(2002). Nanotechnologies for Conservation of Cultural Heritage: Paper and Canvas Deacidification, Langmuir, Vol. 18, No. 21

19_Giorgi, R., Bozzi, C., Dei, L., Gabbiani, C., Ninham, B., \& Baglioni, P. (2005). Nanoparticles of $\operatorname{Mg}(\mathrm{OH}) 2$ : Synthesis and Application to Paper Conservation. Langmuir, 21(18), 8495-8501. doi: 10.1021/la050564m

20_Giorgi, R., Chelazzi, D., \& Baglioni, P. (2005). Nanoparticles of Calcium Hydroxide for Wood Conservation. The Deacidification of the Vasa Warship. Langmuir, 21(23), 10743-10748. doi: 10.1021/la0506731 
21_Giorgi, R., Baglioni, M., Berti, D., \& Baglioni, P. (2010). New Methodologies for the Conservation of Cultural Heritage: Micellar Solutions, Microemulsions, and Hydroxide Nanoparticles. Accounts Of Chemical Research,43(6), 695-704. doi: 10.1021/ar900193h

22_Grøntoft, T., Odlyha, M., Mottner, P., Dahlin, E., Lopez-Aparicio, S., \& Jakiela, S. et al. (2010). Pollution monitoring by dosimetry and passive diffusion sampling for evaluation of environmental conditions for paintings in microclimate frames. Journal Of Cultural Heritage, 11(4), 411-419. doi: 10.1016/j.culher.2010.02.004

23_Hackney, S., \& Ernst, T. (1994). The applicability of alkaline reserves to painting canvases. Studies In Conservation, 39(sup2), 223-227. doi: 10.1179/sic.1994.39.supplement-2.223

24_Hansen, E., Doehne, E., Fidler, J., Larson, J., Martin, B., \& Matteini, M. et al. (2003). A review of selected inorganic consolidants and protective treatments for porous calcareous materials. Studies In Conservation, 48(sup1), 13-25. doi: 10.1179/sic.2003.48.supplement-1.13

25_Łojewski, T., Miśkowiec, P., Missori, M., Lubańska, A., Proniewicz, L., \& Łojewska, J. (2010). FTIR and UV/vis as methods for evaluation of oxidative degradation of model paper: DFT approach for carbonyl vibrations. Carbohydrate Polymers, 82(2), 370-375. doi: 10.1016/j.carbpol.2010.04.087

26_Lundgaard, L., Hansen, W., Linhjell, D., \& Painter, T. (2004). Aging of OilImpregnated Paper in Power Transformers. IEEE Transactions On Power Delivery, 19(1), 230-239. doi: 10.1109/tpwrd.2003.820175

27_Medronho, B., Romano, A., Miguel, M., Stigsson, L., \& Lindman, B. (2012). Rationalizing cellulose (in)solubility: reviewing basic physicochemical aspects and role of hydrophobic interactions. Cellulose, 19(3), 581-587. doi: 10.1007/s10570011-9644-6

28_Poggi, G., Baglioni, P., \& Giorgi, R. (2011). Alkaline Earth Hydroxide Nanoparticles for the Inhibition of Metal Gall Ink Corrosion. Restaurator, 32(3). doi: 10.1515/rest.2011.012 
29_Poggi, G., Toccafondi, N., Melita, L., Knowles, J., Bozec, L., Giorgi, R., \& Baglioni, P. (2013). Calcium hydroxide nanoparticles for the conservation of cultural heritage: new formulations for the deacidification of cellulose-based artifacts. Applied Physics A, 114(3), 685-693. doi: 10.1007/s00339-013-8172-7

30_Rodriguez-Navarro, C., \& Ruiz-Agudo, E. (2018). Nanolimes: from synthesis to application. Pure And Applied Chemistry, 90(3), 523-550. doi: 10.1515/pac-20170506

31_Sandu, I., Brebu, M., Luca, C., Sandu, I., \& Vasile, C. (2003). Thermogravimetric study on the ageing of lime wood supports of old paintings. Polymer Degradation And Stability, 80(1), 83-91. doi: 10.1016/s01413910(02)00386-5

32_Shanani CJ, Harrison G (2002) Spontaneous formation of acids in the natural aging of paper. In: Daniels V, Donnithorne A, Smith P (eds) Works of art on paper: books, documents and photographs. International Institute for Conservation of Historic and Artistic Works, London, pp 189-192

33_ Soares, S., Camino, G., \& Levchik, S. (1995). Comparative study of the thermal decomposition of pure cellulose and pulp paper. Polymer Degradation And Stability, 49(2), 275-283. doi: 10.1016/0141-3910(95)87009-1

34_Taglieri, G., Daniele, V., Mondelli, C., Pusceddu, E. and Trapananti, A. (2013) Synthesis and X-Ray Diffraction Analyses of Calcium Hydroxide Nanoparticles in Aqueous Suspension. Advances in Materials Physics and Chemistry, 3, 108112 . http ://dx.doi.org/10 . 4236/ampc .2013.31A013

35_Taglieri, G., Mondelli, C., Daniele, V., Pusceddu, E., \& Scoccia, G. (2014). Synthesis, Textural and Structural Properties of Calcium Hydroxide Nanoparticles in Hydro-Alcoholic Suspension. Advances In Materials Physics And Chemistry, 04(03), 50-59. doi: 10 . 4236/ampc . 2014.43008 